\title{
Determinants of Inter-port Competition: A Case of Coastal Ports in West Africa
}

\author{
V. Omoke ${ }^{1}$ and D. E. Onwuegbuchunam ${ }^{2}$ \\ 1. Department of Transport Management Technology, Federal University of Technology Minna, P.M.B 65, Minna, Nigeria \\ 2. Department of Maritime Management Technology, Federal University of Technology Owerri, P.M.B 1526, Owerri, Nigeria
}

\begin{abstract}
Ports operating in the same geographical range face significant competition among them. In such setting, less competitive ports may continually lose patronage of shippers (indigenous to them) to adjacent ones with better attributes. The extent of and determinants of inter-port competition in the West Africa's coast are of interest to port administrators/operators who risk losing significant portion of their domestic generated cargo traffic to competing neighbouring ports. In this paper, we explore the question of what port specific attributes serve as competitive basis for West Africa's coastal ports operating in proximity to the other. Through a survey, users of these ports were asked to identify port specific attributes which they consider when deciding which port to use for shipments making. To enrich our empirical model, data collected from the survey were augmented with secondary data (on the identified attributes) obtained from the respective ports. Statistical evidence from data analysis suggests that ports operating in proximity in the West Africa’s coast compete on the basis of attributes that minimise costs for port users, viz: ships’ pre-berthing time, ship turnround time, crane efficiency and availability of cargo spaces (proxied by frequency of ship calls). Policy implications of the findings were discussed.
\end{abstract}

Key words: Port throughput, inter-port competition, ship turnround time, ship calls frequency, crane efficiency.

\section{Introduction}

Globalization, standardization and deregulation are catalysts to port competition. Standardization for example, has enabled seamless movement of shipments between ocean and surface transport through many ports [1] . On the other hand, the emergence of hub ports has relegated many ports to "spokes" or feeder ports and leaving few hub ones [2] . Given the fluid transport environment, many ports are now striving to offer competitive services in order to attract and sustain patronage of users and hence remain in the business of international seaborne trade. Interests of port users have therefore become fundamental to commercial strategy of most ports [3]. Port users essentially comprise of shippers, carriers or shipping lines and freight forwarders. The decision to route cargo through port lies ultimately with the shipper but

Corresponding author: D. E Onwuegbuchunam, Ph.D, research field: Port, logistics \& sea transport modelling. E-mail: don@futo.edu.ng. he may delegate it to the carrier or freight forwarder [4]. Hence port selection decision lies with the shipping lines, the independent shippers and the freight forwarder. Thus the question of competitiveness of ports (i.e. which ports are chosen and why) is ultimately dependent on strategic interests of these major actors.

\subsection{Research Problem and Context}

A pilot survey by the authors on used vehicles' market in some West Africa's ports bordering Nigeria's ports revealed the existence of selling price differences of used vehicles. Specifically, the prices of vehicles in these ports were cheaper in all types and models. Most of the importers of these vehicles were Nigerians and most of the buyers were also Nigerians. Some of the Nigerian importers stated that though their major market was in Nigeria, they had to import through neighbouring ports like Cotonou and Abijan, because it was cost effective to do so. The observed 
preference of neighbouring ports to Nigeria ports by the vehicle shippers is not peculiar to vehicles' market. It applies to other markets involving other cargo types [5]. Extant studies have associated constraints to import procedures in Nigeria ports to lengthy documentation, high cargo clearance and delivery times which range from 10 to 30 days compared to 3 days obtainable in neighbouring ports [6]. Apart from time delays, cost of goods "clearance" and some other applicable charges like demurrage in Nigerian ports are also above most neighbouring ports' average [6]. Against this backdrop, this paper seeks to determine significant factors that explain how ports in the same geographical range with similar attributes are selected by port users. In other words, we seek to determine competitive attributes of the West Africa's ports based on the perspectives of port users.

\section{Review of Related Empirical Studies}

\subsection{Determinants of Port Selection Factors}

Malchow and Kanafani [1] identified factors affecting port selection for export cargo liners in US and found that location, oceanic and inland distances affect port selection, with location being the most important characteristic of a port. Kim, Hong and Shin [7] differentiated external factors from internal factors material to major ports and assessed how these factors changed over time. They found that internal factors were time invariant while the external factors were time variant. $\mathrm{Ng}$ [8] studied container transshipment in northern Europe and found other important factors affecting port user's port attractiveness besides monetary cost. These factors include time efficiency, geographical location and service quality. However, Tongzon and Sawant [9] found port cost and range of port services to be the only significant factors in shipping lines' port choice. Other works were directed at finding whether differences exist in evaluation of port choice criteria among the stakeholders. Murphy, Daley and Dalenberg [10] examined ports, carriers, freight forwarders, larger US shippers and small US shippers. They discovered that there were differences across the groups. Lu [11] investigated the logistic services and strategic dimensions in Taiwanese shipping companies, agencies and freight forwarders and found that the most important strategic dimensions of the maritime companies were value added services, promotion, equipment, facilities, speed and reliability. Acosta, Coronado and Cerban [12] in their exploratory analysis of bunkering competition and competiveness at the ports of Gibraltar Straight found that fuel prices and geographical advantage are two main factors seen by Gibraltar Strait port operators as influencing shipping company choice of bunkering port. In order of importance, other identified factors related to the cost and quantity of services include: port tariffs, supply waiting time, service rates, simplicity of crew changing, presence of restrictive environmental regulations and customs strictness.

Recent studies show that there are a number of common determinants of port competitiveness, though the order may change depending on the port and the type of traffic studied. Onwuegbuchunam [13], Tongzon [4, 14], Lirn, Thanopoulou, Beynon and Beresford [15, 16], Song and Yeo [17] highlight the importance of port infrastructure, geographic location and port costs as the main factor influencing ports competitiveness. Notteboom [18] finds that in addition to traditional factors, excellence in the logistic chain in which the port is involved, is a key determinant. This translates into providing a better service at lower costs for the clients. Under the same geographical context, Acosta, Cerban and Coronado [19] analysed factors influencing port competitiveness between the port of Algeciras Bay and range of competitive ports for container traffic in the Mediterranean. The analysis involved factors related to the quality of services provided-communication technology and degree of competition in intra services and with the logistic chain. The cooperation with the public and private sectors related to the exercise of their activities and ground transportation was also included. They found that three 
main factors determining competitiveness in container traffic are port infrastructure, superstructures and communication technologies. So far, the question of inter port competition in West African coast has been given little or no research attention. The introduction of ECOWAS treaty on free movement of goods and persons has provided a uniform basis for the ports in the region to compete. However, the nature of port competition in the entire region has not been given much research attention. This research attempts to close gaps in knowledge in this direction.

\section{Methodology}

\subsection{A Brief Description of the Study Area}

Western Africa is the westernmost subcontinent of Africa comprising the countries of Benin, Burkina Faso, Cape Verde, Cote d'Ivoire, Equatorial Guinea, the Gambia, Ghana, Guinea, Guinea-Bissau, Liberia, Mali, Mauritania, Niger, Nigeria, Senegal, Sierra Leone, and Togo. It lies between latitudes $4^{\circ} \mathrm{N}$ and $20^{\circ} \mathrm{N}$ and longitude $17^{\circ} 30^{\prime} \mathrm{W}$ and $16^{\circ} \mathrm{E}$. It has a total area of $5,112,903 \mathrm{~km}^{2}$ with a population of 340,000,000 and population density of $49.2 / \mathrm{km}^{2}$. A total number of 40 ports were considered as the port population (comprising very small, small, medium, large and very large ports). Cameroon which is in the central African region was also included because of its relationship with Nigeria and the influence of her ports on Nigerian seaports. With the classification of the ports in the region into very small, small, medium, large and very large ports by three popular port websites (World Port Source.com (WPS), Ports.com and Searates.com), the study focused on small, medium, large and very large ports; leaving out the very small or minor ports that do not attract ocean-going vessels. Hence, eighteen ports were considered.

\subsection{Sources of Data}

Primary data for this study consist of rating responses obtained from copies of questionnaires which were distributed to a random sample of 450 port users: shipping line personnel, shippers and freight forwarders operating in West Africa ports. They were asked to rate port choice factors (in order of importance) on a scale of 1 (least important) to 10 (most important) to obtain relative weights or importance attached. The major aim of the survey was to identify based on port users' perspective, the main port competition variables. Subsequently, secondary data on the identified port competition variables were obtained from terminal records of West African seaports, The World Bank and United Nations Conference on Trade and Development's (UNCTAD) statistical bulletins. Consistent with existing studies, ports within the same region or geographical range can compete on the basis of these variables. Thus, for purposes of this study, the following variables (listed as $i-x$ ) were postulated as port competition variables. In the following sections, port choice and port competitiveness factors will be used interchangeably:

(1) Ship-calls frequency;

(2) Port draught (m);

(3) Quay length (m);

(4) Cargo dwell time (days);

(5) Vessel pre-berth waiting time (hours);

(6) Vessel turnround time (hours);

(7) Truck turnround time (hours);

(8) Crane productivity (tonnes/hour);

(9) Cargo handling charge (per tonne);

(10) LSCI (liner shipping connectivity index).

\subsection{Model Specification and Development}

To address the main research objective, which is to determine significant factors affecting port competition, we derived PCI (Port Competitiveness Index) from the postulated port competitiveness factors using the mathematical model expressed in Eq. (1), see Tongzon and Heng [20].

$$
\mathrm{PCI}=\sum W_{k} X_{i k}
$$

where, PCI represents competitiveness index of all ports in the study, $W_{k}$ denotes the weights (or coefficient) of $k$ th indicator and $\mathrm{X}_{i k}$ is unit free value 


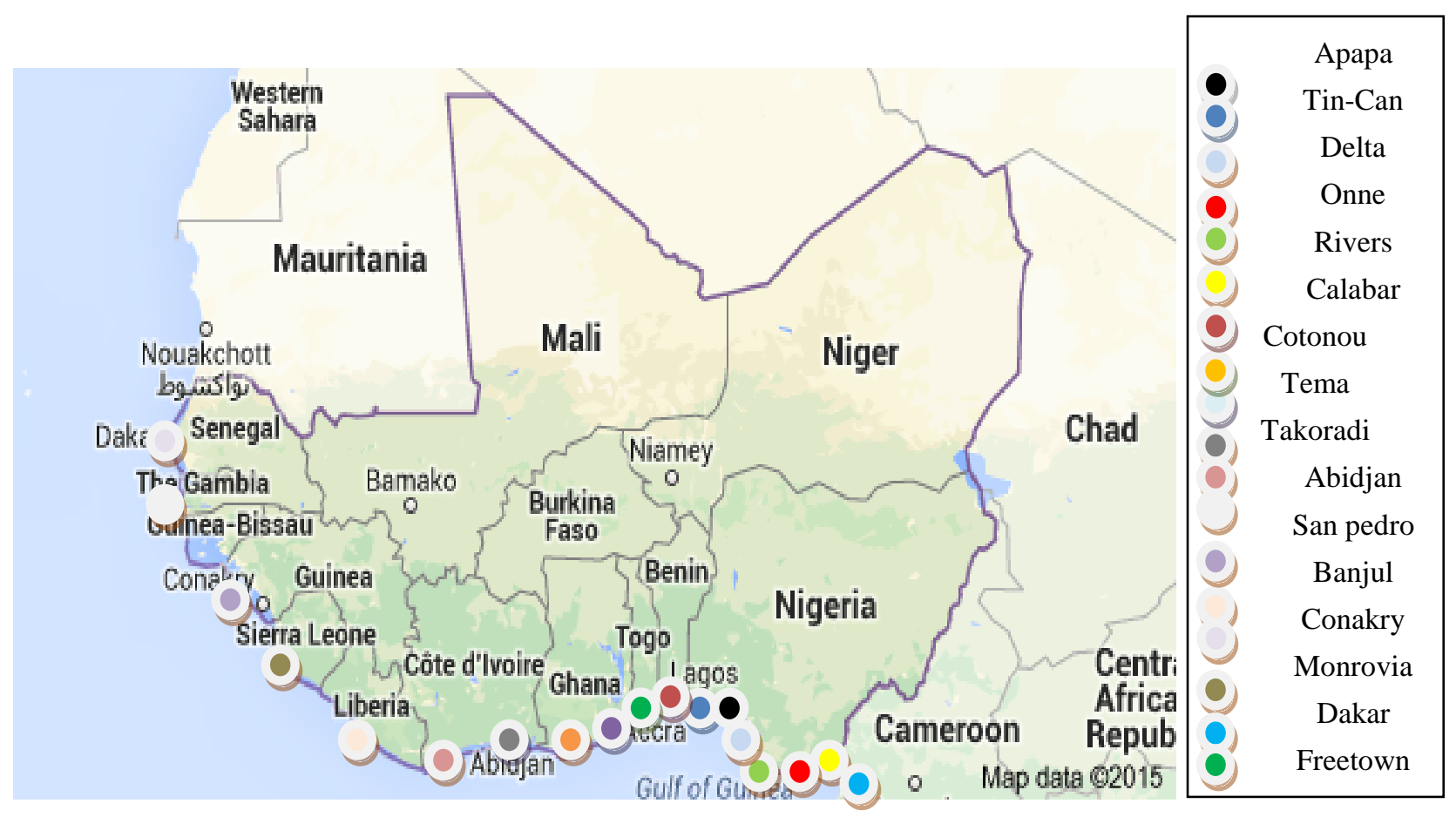

Fig. 1 Geographic location of some West Africa's ports.

Source: http://www.skuld.com.

of the $k$ th indicator for the ports.

The coefficients on computed index represent weights of each variable contributing to the index. We then correlated the PCI with port choice variables to identify its proxy. To derive the PCI based on all ports' choice variables, we applied the technique of factor analysis using principal component technique. The PCI derived using factor analysis correlated with port throughput and this outcome is also consistent with Tongzon and Heng [20]. Hence, total port throughput was taken as proxy of PC (port competitiveness). The statistical model of relationship between port competitiveness and its determinants is shown in Eq. (2) thus:

$$
\mathrm{PC}_{i}=f\left(X_{i k}, \alpha\right)
$$

where, $\mathrm{PC}_{i}$ represents the total throughput of port $i$. The determinants of port competitiveness are then entered into the model as independent variables. The coefficients of these independent variables represent effects of determinants on port competitiveness. In Eqs. (3) and (4), the models (1) \& (2) are operationalized thus:

$$
\begin{aligned}
\mathrm{PCI}= & W_{1} X_{i 1}+W_{2} X_{i 2}+W_{3} X_{i 3}+W_{4} X_{i 4} \\
& +W_{5} X_{i 5}+\ldots+W_{9} X_{i 9}+W_{10} X_{i 10} \\
\mathrm{PC}_{\mathrm{i}} & =\alpha_{0}+\alpha_{1} X_{i 1}+\alpha_{2} X_{i 2}+\alpha_{3} X_{i 3}+\alpha_{4} X_{i 4} \\
& +\alpha_{5} X_{i 5}+\ldots+\alpha_{9} X_{i 9}+\alpha_{10} X_{i 10}+\varepsilon_{i}(4)
\end{aligned}
$$

where,

PCI : is the port competitiveness index for all ports;

$\mathrm{PC}_{\mathrm{i}}$ : is the total throughput by port $i$;

$X_{i 1}$ : Ship-calls frequency;

$X_{i 2}$ : Port draught (m);

$X_{i 3}$ : Quay length (m);

$X_{i 4}$ : Cargo dwell time (days);

$X_{i 5}$ : Vessel pre-berth waiting time (hours);

$X_{i 6}$ : Vessel turnround time (hours);

$X_{i 7}$ : Truck turnround time (hours);

$X_{i 8}$ : Crane productivity (tonnes/hour);

$X_{i 9}$ : Cargo handling charge (per tonne);

$X_{i 10}$ : LSCI;

$\varepsilon_{i}$ : Error term. 


\section{Data Analysis and Discussion}

\subsection{Descriptive Statistics}

In Table 1, the distribution of rating responses of port users according to the survey is presented. The table indicates lowest score, highest score, mean and standard deviation associated with weights or levels of importance attached to port competitiveness factors. The mean scores of the factors provided basis for ranking them, with highest mean score being port throughputs and lowest score corresponding to LSCI. This outcome is understandable given that high throughputs in a particular port may signal high productivity to its users. While LSCI may not be a very important consideration by users proposing to use particular port since it is more related to the nature of home country port's general transport infrastructure. However, the identified factors in Table 1 provided basis for supplementary secondary data collection on the port choice factors.

In Table 2, descriptive statistics of port choice variables obtained from secondary sources are shown. These variables are average values for all the ports. The full data set is attached in appendix as Table A1.

The results of Factor Analysis using the principal component method indicate that only four variables of port competition have significant correlation with PCI, see unedited result output in Tables A2 and A3 in the appendix. These are namely: ship-calls frequency, draught of the port, pre-berthing time of vessels calling

Table 1 Relative weights of port selection criteria.

\begin{tabular}{lllllll}
\hline S/N & Port selection factors & Lowest score & Highest score & Mean score & Standard deviation & Rank \\
\hline 1 & Port throughput (tonnes) & 2 & 10 & 7.124 & 2.923 & 1 \\
2 & Ship-calls frequency & 5 & 9 & 7.012 & 1.491 & 2 \\
3 & Port draught (m) & 5 & 9 & 6.903 & 1.595 & 3 \\
4 & Quay length (m) & 4 & 9 & 6.650 & 1.578 & 4 \\
5 & Cargo dwell time (days) & 3 & 9 & 6.611 & 1.955 & 5 \\
6 & Vessel pre-berth waiting time (hours) & 3 & 9 & 5.901 & 1.912 & 6 \\
7 & Vessel turnround time (hours) & 2 & 9 & 5.520 & 2.369 & 7 \\
8 & Truck turnround time (hours) & 3 & 9 & 5.111 & 1.595 & 8 \\
9 & Crane productivity (tonnes/hour) & 3 & 7 & 4.933 & 1.370 & 9 \\
10 & Cargo handling charge (per tonne) & 3 & 7 & 4.810 & 1.317 & 10 \\
11 & LSCI & 2 & 8 & 4.632 & 2.119 & 11 \\
\hline
\end{tabular}

Source: author, based on survey of port users.

Table 2 Descriptive statistics of port choice variables.

\begin{tabular}{lllll}
\hline Variable & Mean & Std. Dev. & Min. & Max. \\
\hline Port throughputs (m/t) & $9,618,503$ & $6,938,126$ & 887,373 & $23,500,000$ \\
Ship-calls frequency & 999.889 & 758.839 & 197 & 2,858 \\
Port draught (m) & 9.556 & 1.886 & 6 & 13 \\
Quay length (m) & $2,080.833$ & $2,082.193$ & 220 & 6,287 \\
Cargo dwell time (days) & 16.222 & 4.722 & 7 & 23 \\
Vessel pre-berth waiting time (hours) & 31.272 & 12.551 & 3 & 48 \\
Vessel turnround time (hours) & 137.450 & 39.949 & 53 & 201 \\
Truck turnround time (hours) & 8.833 & 4.659 & 3 & 23 \\
Crane productivity (tonnes/hour) & 13.067 & 4.707 & 8 & 17 \\
Cargo handling charge (per tonne) & 12.029 & 2.431 & 9 & 33 \\
LSCI & 22.312 & 10.102 & 8 & \\
No of Obs. = 18 & & & & \\
\hline
\end{tabular}

Source: author's own elaboration based on data obtained from secondary sources. 
at the port, ship turnround time and truck turnround time, see Eq. (5). The PCI correlated significantly with port throughput. The complete statistical model inclusive of all independent variables, with port throughput as the dependent variable was initially estimated. Following an inspection of statistically significant coefficients, a more parsimonious model was estimated using stepwise regression procedure (the unedited stepwise regression output can be found in Table A4).

$$
\begin{gathered}
\text { PCI }=0.627 \text { shipFreq }+0.860 \text { Draught }+ \\
+0.587 \text { berthTime }+0.561 \text { shipTurnrndtime }+ \\
\text { 0.941truckTurntime }
\end{gathered}
$$

In Table 3, we present output of log-linear regression analysis on determinants of port competiveness. From the output, all explanatory variables appear statistically significant (at $\alpha=0.05$ ). Except for ships' pre-berthing time and truck turnround time variables, the signs on the coefficient of the other variables conform to a priori expectation. For example, frequency of ship-calls should signify availability of cargo spaces and hence attracts shippers to ports [4] . In the same vein, increased crane productivity in port leads to increase in ship and cargo handling rates and contributes to port competitiveness. However, the level of ship turnround time at the port is expected to have an inverse relationship with port competitiveness since decrement in its values should attract ship agents/operators to ports and vice versa. The same inverse relationship is expected between ship pre-berthing time, truck turnround time and port competitiveness. However, the observed positive coefficients of pre-berth time and truck turnround time (much against our a priori expectation) may be ignored given the limited number of observations in our data set.

In terms of model fitness statistics, the size of our $F$-statistic and coefficient of variation ( $R$-squared) suggest that the model estimated possesses sufficient explanatory powers and can be adopted for testing hypotheses implied in the study. Therefore, based on the regression model output, the following factors (in increasing order of magnitude of coefficients and ignoring the negative sign) are the determinants of port competition among users of west African ports namely: level of ship turnround times at the port (-1.685), ship-calls frequency in the port (1.243), truck turnround time at the port $(0.870)$, crane productivity (0.754) and pre-berthing time of vessel calling at the ports (0.376).

\subsection{Discussion of Findings}

The study found positive relationship between frequency of ship calls to a port and its competitiveness. High frequency of ship visits translates into more choices for shippers and freight forwarders in selecting a shipping line for transportation of their cargoes. Hence, it can be accepted that more ship visits

Table 3 Multiple Log-linear Regression Model output: Determinants of port competition.

\begin{tabular}{lllll}
\hline Variable & Coef. & Std. Err & $t$-statistic & $\mathrm{P}>|t|$ \\
\hline Shipfreq & 1.243 & 0.178 & 6.990 & 0.000 \\
BerthTime & 0.376 & 0.173 & 2.180 & 0.050 \\
VslTurntime & -1.685 & 0.358 & -4.710 & 0.001 \\
TruckTurntime & 0.870 & 0.329 & 2.650 & 0.021 \\
CraneProd & 0.754 & 0.320 & 2.350 & 0.036 \\
Intercept & 10.855 & 2.073 & 5.240 & 0.000 \\
\hline Model fitting information & & & \\
\hline No of Obs. = 18 & & & \\
F $(5,12)=16.76$ & & & \\
prob. $>F=0.0214$ & & & \\
$R$-squared $=0.8748$ & & & \\
\hline
\end{tabular}

Source: author; dependent variable: port through put, variables in natural logs. 
lower transportation cost by allowing more competition among carriers and attracting more users by providing them with more choices [21, 22]. Ships turnround time which is the major variable of time efficiency has an inverse relationship with port's competitiveness. The lower the ships turnround times, the higher the competitiveness of a port. Lower ship and truck turnround times translate to cost savings to ship owners, charterers and operators using the port. This finding agrees with that of $\mathrm{Ng}$ [8], Lu [11], Ha [23] and Acosta et al. [12, 19]. Lower pre-berthing time of vessels on arrival amounts to cost savings by ship owners and operators. Crane productivity is another efficiency measure found to be positively related to port competitiveness. Other studies have reinforced its importance in port selection. Prominent among them are Saeed [24] and Sayarah and Razaee [25]. The findings are consistent with that of Dyck and Ismael [26].

\section{Conclusions and Recommendation}

Our findings in this work indicate that coastal ports within the West African sub-region compete on the basis of attributes that minimise costs for port users: ships’ pre-berthing time, ship turnround time, crane efficiency and availability of cargo spaces (proxied by frequency of ship calls). Therefore, terminal operators and indeed port administration in Nigeria should streamline their port improvement efforts towards these port-specific attributes. All the identified competitive factors except frequency of ship-calls underscore the need for efficiency of cargo or ship operation in ports [27]. Thus, minimum time spent by ship or cargo in port as a result of improved ship and cargo operation, ultimately results in cost savings by port users. This can be achieved with total electronic integration of all aspects of ship and port operation connecting all stakeholders. This is presently lacking in Nigeria ports. Electronic integration of Nigeria's port community is suggested as a step in enhancing information and material flow during cargo and ship operation. Future research should focus on evaluating the effect of information technology application and integration on port competitiveness.

\section{References}

[1] Malchow, M., and Kanafani, A. 2004. “A Disaggregate Analysis of Port Selection.”Transportation Research Part E 40: 317-37.

[2] Chang, Y. T., Lee, S. Y., and Tongzon, J. T. 2008. "Port Selection Factors by Shipping Lines: Different Perspectives between Trunk Liners and Feeder Service Providers.” MarinePolicy 32: 877-85.

[3] Onwuegbuchunam, D. E, Okeke, K. O, Igboanusi, C., and Ugboma, O. 2018. "Structural Changes in the Global Transport Chain: Implications For Ports.” Journal of Sustainable Development of Transport and Logistics, 3 (1): 22-8. doi:10.14254/jsdtl.2018.3-1.2.

[4] Tongzon, J. L. 2002. Port Choice Determinants in a Competitive Environment. Department of Economics. National University of Singapore.

[5] Chikere, C. A., Ibe, C. C., Mobolaji, S. S., Obiagali, N. N., and Ukpere, W. I. 2014. "Motivating Factors for Cargo Diversion from Nigeria to Neighbouring Ports." Journal of Economics 5 (1): 77-86.

[6] Omoke, V. 2008. "Analysis of Cargo Tracking System: A Focus on Nigerian Seaports.” Unpublished M.Sc. thesis, Submitted to the Department of Transport Management Technology, Federal University of Technology, Owerri.

[7] Kim, Y., Hong, G., and Shin, C. 2004. "An Empirical Study on Port Selection Criteria.” Journal of Korean Navigation and Port Research 28 (6): 525-30.

[8] Ng, K. Y. 2006. "Assessing the Attractiveness of in the North European Container Transhipment Market: An Agenda for Future Research in Port Competition.” Maritime Economics and Logistics 8 (3): 234-41.

[9] Tongzon, J. L., and Sawant, L. 2007. "Port Choice in a Competitive Environment: Form the Shipping Lines' Perspective.” Applied Economics 39: 477-92.

[10] Murphy, P., Daley, J. A., and Dalenberg, D. 1992. "Port Selection Criteria: An Application of a Transport Research Framework." Logistics and Transportation Review 28 (3): 237-55.

[11] Lu, C. 2000. "Logistics Services in Taiwanese Maritime Firms.” Transportation Research Part E 36 (2): 79-96.

[12] Acosta, M., Coronado, D., and Cerban, M. 2011. "Bunkering Competition and Competitiveness at the Ports of the Gibraltar Strait." Journal of Transport Geography 19 (4): 911-6.

[13] Onwuegbuchunam, D. E. 2013. "Port Selection Criteria by Shippers in Nigeria: A Discrete Choice Analysis.” 
International Journal of Shipping and Transport Logistics 5 (4/5): 532-50.

[14] Tongzon, J. L. 2007. "Determinants of Competitiveness in Logistics: Implications for the ASEAN Region.” Maritime Economics and Logistics 9: 69-83.

[15] Lirn, T. C., Thanopoulou, H. A., and Beresford, A. K. C. 2003. "Transhipment Port Selection and Decision-Making Behaviour: Analysing the Taiwanese Case.” International Journal of Logistics Research and Applications 6: 229-44.

[16] Lirn, T. C., Thanopoulou, H. A., Beynon, M. J., and Beresford, A. K. C. 2004. "An Application of AHP on Transhipment Port Selection: A Global Perspective.” Maritime Economics and logistics 6: 70-91.

[17] Song, D. W., and Yeo, G. T. 2004. “The Hierarchical Analysis of Perceived Competitiveness: An Application to Korean Container Ports.” Journal of the Eastern Asia Society for Transport Studies 6: 866-80.

[18] Notteboom, T. 2008. "The Relationship between Seaports and the Intermodal Hinterland in Light of Global Supply Chains.” Discussion Paper No. 10, Joint Transport ResearchCentre, OECD.

[19] Acosta, M., Cerban, M., and Coronado, D. 2007. "Port Competitiveness in Container Traffic from an Internal Point of View: The Experience of the Port of Algeciras Bay.”MaritimePolicy and Management 34: 499-518.

[20] Tongzon, J. L., and Heng, W. 2005. "Port Privatization, Efficiency and Competitiveness: Some Empirical
Evidence from Container Ports (Terminals).” Transportation Research Part A 39: 405-24.

[21] Tongzon, J. L. 2009. "Port Choice and Freight Forwarders.”Transportation Research Part E: Logistics and Transportation Review 45 (1): 185-95.

[22] De Langen, P. W. 2007. "Port Competition and Selection in a Contestable Hinterland: The Caseof Austria." European Journal of Transport and Infrastructure Research 7 (1): 1-14.

[23] Ha, M. S. 2003. “A Comparison of Service Quality at Major Container Ports: Implications for Korea Ports.” Journal of Transport Geography 11: 131-7.

[24] Saeed, N. 2009. “An Analysis of Carriers' Selection Criteria when Choosing Container Terminalin Pakistan.” Maritime Economic and Logistics 11 (3): 270-88.

[25] Sayareh, J., and Rezaee, A. H. 2014. “A Hybrid Decision-Making Model for Selecting Container Seaport in the Persian Gulf.” The Asian Journal of Shipping and Logistics 30 (1): 75-95.

[26] Dyck, G. K., and Ismael, H. M. 2015. "Multi-criteria Evaluation of Port Competitiveness in West Africa Using Analytical Hierarchical Process (AHP).” American Journal of Industrial and Business Management 5 (6): 432-46.

[27] Onwuegbuchunam, D. E, 2018. “Assessing Port Governance, Devolution and Terminal Performance in $\begin{array}{llll}\text { Nigeria." } \quad \text { Logistics } & 2 & \text { (6) }\end{array}$ doi:10.3390/logistics2010006. 
Appendix A

Table A1 Data on port competitive factors.

\begin{tabular}{|c|c|c|c|c|c|c|c|c|c|c|c|c|}
\hline $\mathrm{S} / \mathrm{N}$ & Ports & $\begin{array}{l}\text { Port } \\
\text { throughput } \\
\text { (PT) }\end{array}$ & $\begin{array}{l}\text { Frequency } \\
\text { of ship calls } \\
\left(\mathrm{X}_{1}\right)\end{array}$ & $\begin{array}{l}\text { Draught } \\
\left(\mathrm{X}_{2}\right)\end{array}$ & $\begin{array}{l}\text { Quay length } \\
\left(\mathrm{X}_{3}\right)\end{array}$ & $\begin{array}{l}\text { Cargo dwell } \\
\text { time }\left(\mathrm{X}_{4}\right)\end{array}$ & $\begin{array}{l}\text { Ship pre-berth } \\
\text { Waiting Time } \\
\left(\mathrm{X}_{5}\right)\end{array}$ & $\begin{array}{l}\text { Ship } \\
\text { turnround } \\
\text { time }\left(\mathrm{X}_{6}\right)\end{array}$ & $\begin{array}{l}\text { Truck } \\
\text { turnround } \\
\text { time }\left(\mathrm{X}_{7}\right)\end{array}$ & $\begin{array}{l}\text { Crane } \\
\text { productivity } \\
\left(\mathrm{X}_{8}\right) \\
\end{array}$ & $\begin{array}{l}\text { Cargo handling } \\
\text { charge per ton } \\
\left(\mathrm{X}_{9}\right)\end{array}$ & $\begin{array}{l}\text { Liner shipping } \\
\text { connectivity index } \\
\text { (LSCI) }\left(\mathrm{X}_{10}\right)\end{array}$ \\
\hline 1 & Apapa & $21,730,426$ & 1,498 & 9.3 & 3,459 & 21 & 36 & 136.8 & 6 & 15 & 10.47 & 32.68 \\
\hline 2 & Tin-Can & $16,103,981$ & 1,725 & 9.5 & 4,763 & 20 & 34 & 103.2 & 5 & 13.8 & 10.47 & 32.68 \\
\hline 3 & Delta & 8,930,367 & 498 & 6.2 & 6,287 & 23 & 32 & 93.6 & 14.7 & 8 & 10.47 & 32.68 \\
\hline 4 & Onne & $23,478,848$ & 820 & 10.8 & 4,912 & 14 & 24 & 62.4 & 4.2 & 14 & 10.47 & 32.68 \\
\hline 5 & Rivers & $4,924,857$ & 447 & 7.6 & 2,369 & 23 & 38.4 & 184.8 & 16.2 & 11 & 10.47 & 32.68 \\
\hline 6 & Calabar & $1,718,518$ & 197 & 6.2 & 1,004 & 20 & 34 & 163.2 & 15.4 & 8.4 & 10.47 & 32.68 \\
\hline 7 & Cotonou & $7,805,503$ & 1,105 & 11 & 220 & 15 & 48 & 161 & 6 & 15 & 9 & 17.67 \\
\hline 8 & Tema & $12,180,615$ & 1,553 & 9.1 & 2,413 & 20 & 9.6 & 152 & 8 & 14 & 10 & 21.85 \\
\hline 9 & Takoradi & $5,452,025$ & 1,364 & 9.5 & 714 & 19 & 10 & 154 & 7 & 8 & 10 & 21.85 \\
\hline 10 & Abidjan & $21,476,565$ & 2,278 & 12.5 & 840 & 12 & 2.9 & 52.8 & 2.5 & 16 & 14 & 31.35 \\
\hline 11 & San Pedro & $4,738,021$ & 392 & 11.5 & 736 & 15 & 25 & 107.3 & 8 & 9 & 14 & 31.35 \\
\hline 12 & Banjul & $1,958,484$ & 364 & 10 & 750 & 13 & 32 & 140.8 & 7 & 18 & 13 & 8.21 \\
\hline 13 & Conakry & 7,193,636 & 356 & 8.5 & 1,159 & 11 & 38 & 127.2 & 9 & 14 & 14.7 & 9.01 \\
\hline 14 & Monrovia & $7,452,492$ & 368 & 9.2 & 609 & 14 & 42 & 150.9 & 12 & 22 & 12.8 & 8.47 \\
\hline 15 & Dakar & $11,869,557$ & 2,858 & 10 & 6,025 & 7 & 36 & 201.2 & 5 & 8 & 15.2 & 12.19 \\
\hline 16 & Freetown & 887,373 & 214 & 9.4 & 505 & 9 & 35 & 147.5 & 11 & 10 & 15.2 & 12.19 \\
\hline 17 & Douala & $6,533,255$ & 841 & 7.5 & 440 & 19 & 46 & 174.4 & 18 & 8 & 16.8 & 10.96 \\
\hline 18 & Lome & $8,698,524$ & 1,120 & 11.5 & 250 & 17 & 40 & 161 & 4 & 23 & 9 & 20.44 \\
\hline
\end{tabular}

Source: Compiled data based on port terminal records; port websites; UNCTAD and World Bank statistical bulletins; various issues. 
Table A2 Results of factor analysis using principal components method.

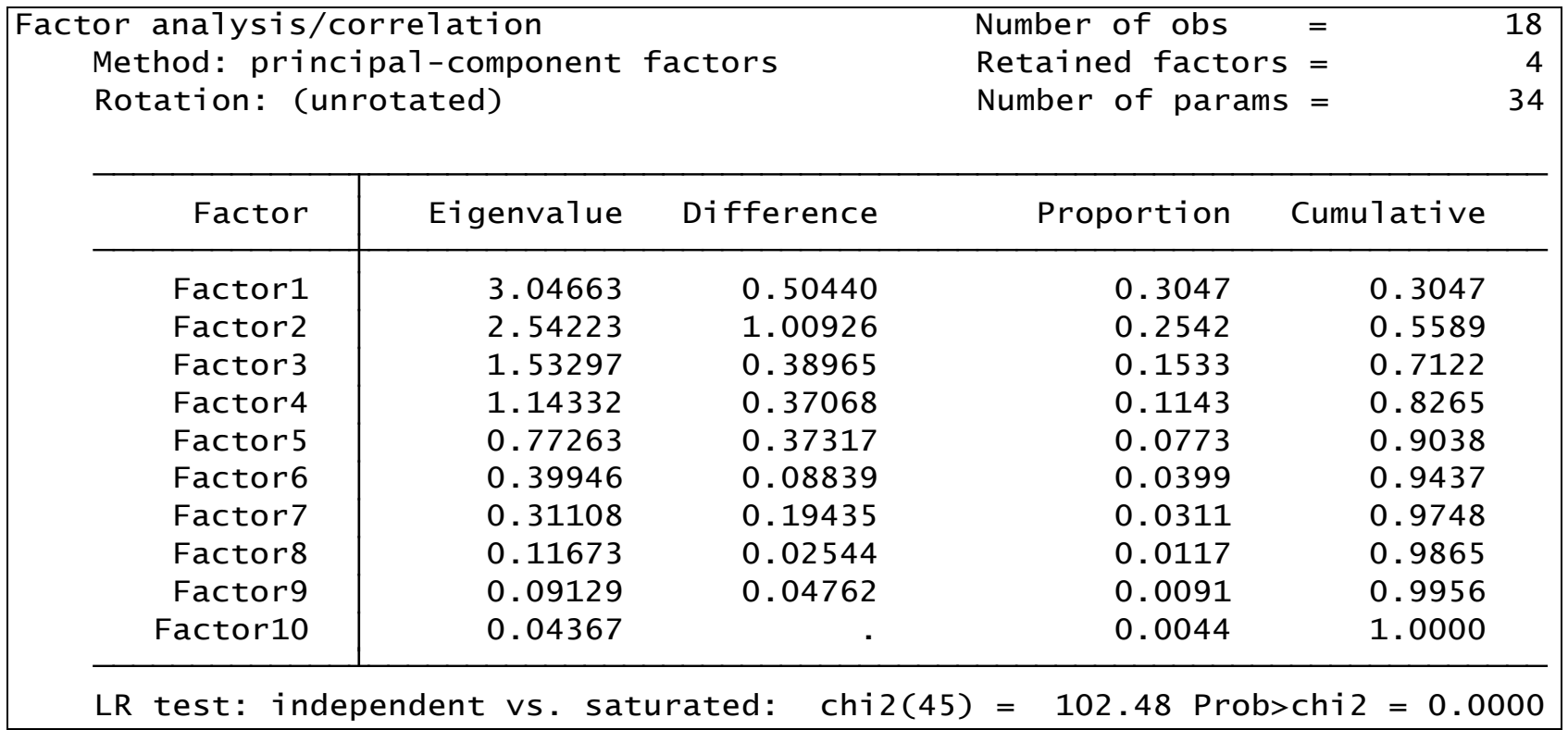

Table A3 Therotated factor matrix's output.

\begin{tabular}{|r|rrrr|r|}
\hline Variab1e & Factor1 & Factor2 & Factor3 & Factor4 & Uniqueness \\
\hline x1 & -0.6278 & 0.0794 & 0.4222 & 0.5290 & 0.1414 \\
×2 & -0.8595 & -0.3014 & -0.1561 & -0.0575 & 0.1428 \\
×3 & -0.0960 & 0.5503 & 0.5089 & 0.4018 & 0.2675 \\
x4 & 0.3914 & 0.7689 & -0.3290 & 0.0651 & 0.1431 \\
×5 & 0.5872 & -0.3440 & -0.2146 & 0.4062 & 0.3258 \\
x6 & 0.5610 & -0.3642 & -0.0080 & 0.5803 & 0.2159 \\
x7 & 0.9414 & 0.0765 & 0.0732 & -0.2054 & 0.0604 \\
x8 & -0.3954 & -0.3048 & -0.7345 & 0.1542 & 0.1875 \\
x9 & 0.1211 & -0.6325 & 0.6092 & -0.3280 & 0.1065 \\
x10 & -0.1864 & 0.8951 & -0.0318 & -0.1387 & 0.1438 \\
\hline
\end{tabular}


Table A4 Stepwise regression procedure.

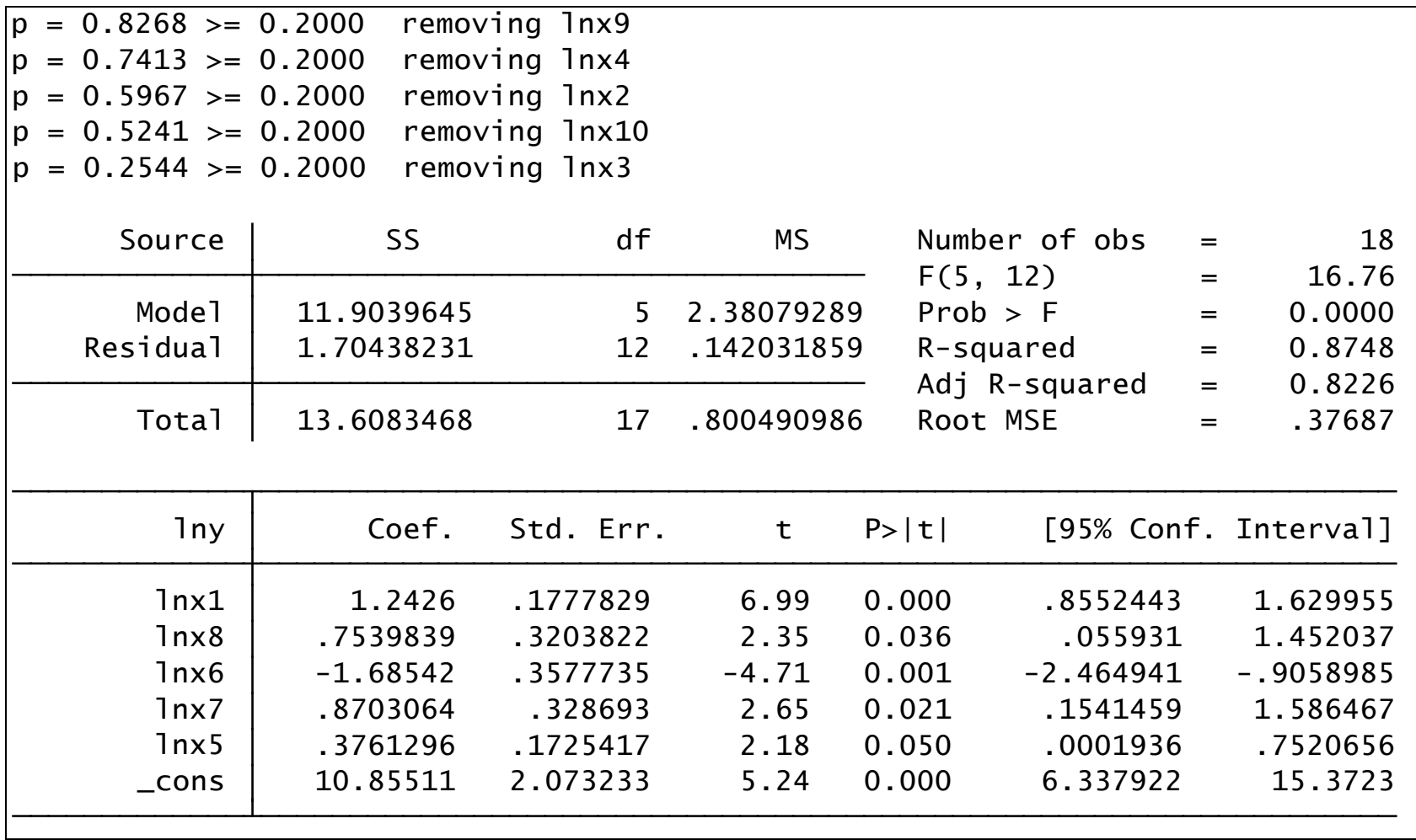

